\title{
On the Correlation of Exchange Rates and Interest Rates
}

\author{
Charles M. Engel* \\ Rouss Hall, Department of Economics, University of Virginia, Charlottesville \\ $V A$ 22901, US $A$
}

This note shows that a negative correlation between the price of foreign currency and nominal interest rates is not necessarily an indication of movements in the real rate of interest. Such a correlation could be consistent with a monetarist model in which the real rate is constant.

This note is aimed at correcting the misimpression that a negative correlation between the price of foreign currency and nominal interest rates is necessarily evidence of a change in the real interest rate. For example, Jacob Frenkel, 1983, p. 52, has stated, 'By and large, since the latter part of 1979 , the high nominal rate of interest in the United States has been accompanied by an appreciation of the dollar. This suggests that the important factor underlying the evolution of the nominal rate of interest in the United States has been the evolution of the real rate of interest rather than inflationary expectations.' (See also Frenkel and Michael Mussa, 1981, p. 257; or Bradford Cornell and Alan Shapiro, 1984.) A similar problem is the loose statement that in the monetarist model of exchange rate determination, in which real rates are constant, there is a positive relation between interest rates and exchange rates (see Jeffrey Frankel, 1979, p. 610; Rudiger Dornbusch, 1980, p. 146).

Generally, these statements concerning the correlation between interest rates and exchange rates are simply made as a rough and ready contrast between the implications of monetarist (Frenkel, 1976) and sticky-price (Dornbusch, 1976) models of exchange rate determination. However, the problems with putting much reliance on correlations of endogenous variables are well known. This note is a friendly reminder that this type of correlation is not very useful even in distinguishing exchange-rate models. Some examples follow of a monetarist model, in which the real rate of interest is constant, but there is a negative correlation between interest rates and exchange rates (when expressed as units of domestic currency per unit of forcign currency).

\section{A Simple Monetarist Model}

This section presents a simple monetarist model based on Mussa, 1976, in which the exchange rate and nominal interest rates are negatively correlated.

* I would like to thank Jeffrey Frankel for comments and encouragement on this note. 0261-5606/86/01/0125-4\$03.00 (C) 1986 Butterworth \& Co (Publishers) Ltd 
There is a Cagan money demand function, in which real money demand depends on the nominal rate of interest and real income. Real output is assumed to be exogenous and fixed, so the log of output is set to zero. The real interest rate, $r$, is constant for all time. We have

$$
m_{t}-p_{t}=-\lambda i_{t}=-\lambda\left(E_{t} p_{t+1}-p_{t}\right)-\lambda r .
$$

In this equation, $m$ and $p$ are the logs of the money supply and price level, respectively, and $E_{t} p_{t+1}$ is the expectation at time $t$ of the log of the period $t+1$ price level.

Purchasing power parity is assumed to hold. The foreign price level is taken to be constant, and so its log is set to zero. Then $s_{t}=p_{t}$, where $s$ is the log of the exchange rate. It is convenient also to assume the foreign interest rate, $i^{*}$, is constant.

With the additional assumption of rational expectations, some specification of the money supply process is necessary to close the model. The money supply is assumed to be white noise:

$$
m_{t}=\bar{m}+u_{t} .
$$

In this expression, $\bar{m}$ is a target money supply, and $u$ is a serially uncorrelated, zero mean error term. In words, there is a target money stock, but there can be transitory deviations.

It is easy to see that a linear solution to the model is given by:

$$
\begin{aligned}
s_{t} & =p_{t}=\bar{m}+\lambda r+\frac{1}{1+\lambda} u_{t} ; \\
E_{t} p_{t+1} & =\bar{m}+\lambda r \\
i_{t} & =-\frac{1}{1+\lambda} u_{t}+r .
\end{aligned}
$$

Notice that $\operatorname{Cov}\left(s_{t}, i_{t}-i^{*}\right)=-[1 /(1+\lambda)]^{2} \operatorname{Var}\left(u_{i}\right)$. Intuitively, when the money supply jumps up, prices and the exchange rate rise. But, since the money supply is expected to return to its target level, expected inflation and the interest rate fall. Hence, there is a negative correlation between the exchange rate and the interest rate.

The above model is not a very likely model of the world. It implies exchange rates are stationary, whereas evidence (see Richard Meese and Kenneth Singleton, 1982) suggests there are unit roots in the equations of motion for the exchange rate. It also implies negative serial correlation of inflation, whereas, in fact, inflation is positively serially correlated.

\section{A More Complicated Monetarist Model}

Both of these objections to the above model can be taken care of by adding a growth term to the money supply process that is positively serially correlated. Hence, replace equation $\langle 2\rangle$ with $\langle 3\rangle,\langle 4\rangle$ and $\langle 5\rangle$ :

$$
\begin{gathered}
m_{t}=\bar{m}_{t}+u_{t} \\
\bar{m}_{t}=\bar{m}_{t-1}+\mu_{t} \\
\mu_{t}=\rho \mu_{t-1}+\varepsilon_{t}
\end{gathered}
$$


It is fairly easy to see that a linear solution to this model is given by

$$
\begin{aligned}
& s_{t}=p_{t}=\bar{m}_{t-1}+\frac{\rho(1+\lambda)}{1+\lambda(1-\rho)} \mu_{t-1}+\frac{1+\lambda}{1+\lambda(1-\rho)} \varepsilon_{t}+\frac{1}{1+\lambda} u_{t}+\lambda r \\
& i_{t}=\frac{\rho^{2}}{1+\lambda(1-\rho)} \mu_{t-1}+\frac{\rho}{1+\lambda(1-\rho)} \varepsilon_{t}-\frac{1}{1+\lambda} u_{t}+r .
\end{aligned}
$$

The exchange rate does not have finite variance given that $\bar{m}_{i-1}$ does not. Thus, it makes sense to look at the covariance of the change in the exchange rate with the change in the interest rate. We have

$$
\operatorname{Cov}\left(i_{t+1}-i_{t}, s_{t+1}-s_{t}\right)=\frac{\rho[1+\lambda(1+\rho)]}{(1+\rho)[1+\lambda(1-\rho)]^{2}} \operatorname{Var}\left(\varepsilon_{t}\right)-\frac{2}{(1+\lambda)^{2}} \operatorname{Var}\left(u_{i}\right) .
$$

This correlation is negative so long as

$$
\operatorname{Var}\left(u_{t}\right)>\frac{(1+\lambda)^{2} \rho\left[1-\rho+\lambda\left(1-\rho^{2}\right)\right]}{2\left(1-\rho^{2}\right)[1+\lambda(1-\rho)]^{2}} \operatorname{Var}\left(\varepsilon_{t}\right)
$$

This model can also produce the desired positive serial correlation of inflation. Letting $\pi_{t}=p_{t+1}-p_{t}$,

$$
\operatorname{Cov}\left(\pi_{t+1}, \pi_{t}\right)=\frac{\rho\left[1+\lambda\left(1-\rho^{2}\right)\right]}{\left(1-\rho^{2}\right)[1+\lambda(1-\rho)]^{2}} \operatorname{Var}\left(\varepsilon_{t}\right)-\frac{1}{(1+\lambda)^{2}} \operatorname{Var}\left(u_{t}\right) .
$$

This correlation is positive when

$$
\operatorname{Var}\left(u_{l}\right)<\frac{(1+\lambda)^{2} \rho\left[1+\lambda\left(1-\rho^{2}\right)\right]}{\left(1-\rho^{2}\right)[1+\lambda(1-\rho)]^{2}} \operatorname{Var}\left(\varepsilon_{t}\right)
$$

In order for equations $\langle 6\rangle$ and $\langle 7\rangle$ to hold we need

$$
\begin{aligned}
\frac{(1+\lambda)^{2} \rho\left[1-\rho+\lambda\left(1-\rho^{2}\right]\right.}{2\left(1-\rho^{2}\right)[1+\lambda(1-\rho)]^{2}} \operatorname{Var}\left(\varepsilon_{t}\right)< & \operatorname{Var}\left(u_{t}\right) \\
& <\frac{(1+\lambda)^{2} \rho\left[1+\lambda\left(1-\rho^{2}\right)\right]}{\left(1-\rho^{2}\right)[1+\lambda(1-\rho)]^{2}} \operatorname{Var}\left(\varepsilon_{t}\right) .
\end{aligned}
$$

For example, if $\lambda=1$ and $\rho=0.95$, then we must have

$$
2.6 \operatorname{Var}\left(\varepsilon_{t}\right)<\operatorname{Var}\left(u_{t}\right)<38.8 \operatorname{Var}\left(\varepsilon_{t}\right) \text {. }
$$

Transitory shocks must be more variable than shocks to the growth rate, but not too variable.

So, the model in this section has many features that jibe with empirical evidence, including a non-stationary exchange rate and positive serial correlation of inflation. It also has a negative relation between (changes in) exchange rates and (changes in) interest rates. Since the real rate is constant, such a correlation cannot be said to have arisen from a liquidity effect.

\section{Conclusions}

Can these monetarist models be said to explain plausibly events in the real world? The negative correlation between (changes in) exchange rates and 
(changes in) interest rates arises if as prices (inflation) jump up, expected inflation (changes in inflation) falls. This behavior might be expected when the monetary authority is targeting the money stock. Thus, the monetarist models presented in the note are wholly consistent with the observation that a strong negative correlation between the exchange rate and interest rates began to emerge late in 1979, after the Fed began targeting money (see Cornell and Shapiro, 1984; Frenkel, 1983).

Examination of the money demand equation $\langle 1\rangle$ seems to suggest that as interest rates go up, prices, and hence exchange rates, should rise. Why, then, were we able to produce an example where there is negative correlation between these variables? In a regression of exchange rates on interest rates, the interest rate is likely to be correlated with the error term. The error term comes from changes in the money stock. In these nodels, as the money stock jumps up, expected inflation and the interest rate fall.

How might one legitimately reject the monetarist model? One way is suggested by Engel and Frankel, 1984, who use data on weekly money announcements. That paper shows that the monetarist model implies that the correlation between the change in the exchange rate at the time of the money announcement and the unexpected part of the announced change in the money supply, should be of the same sign as the correlation between the change in the interest rate and the unexpected part of the announced change in the money supply. The evidence strongly demonstrates these correlations are of opposite sign. These regressions work simply because the regress and-the surprise in the money announcement - is legitimately econometrically exogenous. It is a regression of an endogenous variable on an exogenous variable. This is much preferable to correlating two endogenous variables.

\section{References}

Cornell, B. AND A. Shapiro, 'Testing for the Existence of a Liquidity Effect,' unpublished, UCLA Graduate School of Management, February 1984.

Dornbusch, R., 'Expectations and Exchange Rate Dynamics,' Journal of Political Economy, December 1976, 84: 1161-1176.

Dornbusch, R., 'Exchange Rate Economics: Where Do We Stand?' Brookings Papers on Economic Activity, 1980 (1), pp. 143-205.

ENGel, C. ANd J. Frankel, "Why Interest Rates React to Money Announcements: An Explanation from the Foreign Exchange Market,' Journal of Monetary Economics, January 1984, 13: 31-40.

Frankel, J., 'On the Mark: A Theory of Floating Exchange Rates Based on Real Interest Differentials,' American Economic Review, September 1979, 69: 610-622.

Frenkel, J., ' $\Lambda$ Monetary $\Lambda$ pproach to the Exchange Ratc: Doctrinal Aspects and Empirical Evidence,' Scandinavian Journal of Economics, May 1976, 78: 200-224.

Frenkel, J., 'Monetary Policy: Domestic Targets and International Constraints,' American Economic Revien, May 1983, $73:$ 48-53.

Frenkel, J. and M. Mussa, 'Monetary and Fiscal Policies in an Open Economy,' American Economic Review, May 1981, 71: 253-258.

Meese, R. ANd K. Singleton, 'On Unit Roots and the Empirical Modeling of Exchange Rates,' Journal of Finance, September 1982, 37: 1029-1035.

Mussa, M., 'The Exchange Rate, the Balance of Payments and Monetary and Fiscal Policy under a Regime of Controlled Floating', Scandinavian Journal of Economics, May 1976, 78: 229-248. 